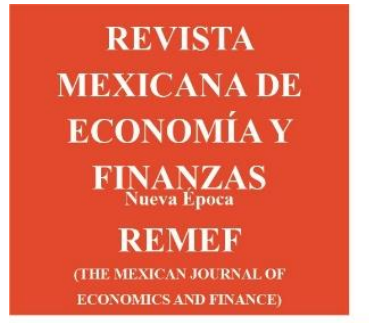

Revista Mexicana de Economía y Finanzas, Nueva Época

Volumen 15 Número 4, Octubre - Diciembre 2020, pp. 621-645

DOI: https://doi.org/10.21919/remef.v15i4.557

(Recibido: 14/mayo/2020, aceptado: 27/agosto/2020)

Special Issue: Energy \& Growth

Guest Editor: Ilhan Ozturk, Ph.D.

\title{
Energy, Growth and Environment: Analysis from the Microeconomics Perspective
}

\section{Abstract}

\author{
Erico Wulf Betancourt ${ }^{1}$ \\ University of La Serena. Chile
}

The tradeoff between environment, growth, and development has been an issue of increasing concern for academic research. This paper, propose a theoretical model of Endogenous Efficiency decision (choice) in the firm, to understand the relationship between energy, production and growth. The literature and empirical evidence, is reviewed for all the variables involved. It is assumed that profit -utility maximizing economic agent, make management decisions out of a CES function, the key to get the production mix efficiency. The proposed model, and its maximizing utility- profit purpose out of human capital investment, do fit empirical evidence about the East Asian countries economic growth case (1950-1995). Further research, is recommended to test the CES management production function, to explain energy and growth relationships. A relevant limitation, is the lack of a comprehensive format, about the macro and microeconomics variable specifications, which influence economic growth. Finally, missing the role of management, has a biased effects for policy recommendation to get a better approach, to solve the tradeoff between energy and growth.

JEL Classification: D83, F64, J24, L23, M11, O44

Keywords: Bounded Rationality, Globalization, Human Capital, Firm Organization, Management, Economic growth.

\section{Energía, crecimiento y medio ambiente: análisis desde la perspectiva de la microeconomía}

\section{Resumen}

La interacción entre el medio ambiente, el crecimiento y el desarrollo económico, ha sido un tema de interés creciente para la investigación académica. El presente artículo, propone un modelo teórico de decisión endógena de la eficiencia en la empresa, para comprender la interrelación entre energía, producción, y crecimiento. Se revisan la literatura y la evidencia empírica de las variables consideradas. Se asume que agentes económicos motivados por la maximización de sus utilidades y beneficios, toman decisiones de gestión desde una función CES, para lograr un mix eficiente de producción.

El modelo propuesto y la hipótesis de maximización de la utilidad derivada del capital humano, se ajusta con la evidencia de las economías del sudeste asiático (1950-1990).Más investigación es necesaria, acerca de la función de gestión de producción CES, y la relación entre energía y crecimiento. Una limitación, es la carencia de un formato inclusivo de las variables macro y microeconómicas, que influyen el crecimiento económico.Finalmente, la omisión del rol de la gestión, tiene un impacto sesgado en las recomendaciones de política respecto de la interacción energía - crecimiento.Palabras claves: Racionalidad acotada, Globalización, Capital Humano, Organización de la empresa, gestión, crecimiento económico. Clasificación JEL: D83, F64, J24, L 23, M 11, O44

Palabras clave: Racionalidad acotada, Globalización, Capital Humano, Organización de la empresa, gestión, crecimiento económico

${ }^{1}$ ORCID ID: 0000-0002-3863-3263

Email: ewulf@userena.cl

* Sin fuente de financiamiento para el desarrollo de la investigación 


\section{Introduction}

In recent years, the search for higher efficiency in production process, has made a more relevant issue to think about the microeconomics foundations, of the relationship between energy, environment and growth. Private firms and its production technology, are moving slowly away from their fossil energy dependence. Moreover, the role nongovernment organizations, along with a better institutional framework for environmental resources, have become a key input to get the goal of sustained expansion of prosperity.

To get an energy efficient input mix in the long run, efficiency and productivity gains, are necessary. These gains to be efficient and effective, should come about from different sources, such as technological, business models, management decisions, institutional guidelines, and regulatory policies.

While the oil crisis in the mid seventy, boosted energy as a key resource due to its technological and cost impact in the input production mix, the current status of increasing concern about energy, growth and environment, make relevant to address properly the role of its microeconomics foundation, especially the management decisions about those endogenous forces leading to higher efficiency in the firm.

Moreover, the traditional accounting approach for economic growth, does not seem to provide a reliable source for policy recommendation, as much as it deals only with inputs quantity and its ex post outcome. Besides, its empirical evidence, has led to contradictory results, about the causality relationship among its key variables, regarding the tradeoff between energy and growth.

This paper's methodology is based upon reviewing the empirical evidence, which explain the causality relationships between energy and growth. Then, an Endogenous efficiency choice (decisions) model, is proposed as an integrated growth synthesis, with an explicit management variable to solve the production input mix, throughout a reformulation of the CES production function. The experience of management in mining industry, its governance principles, and its approach to deal with its output operation, and its environment protection corporate policies, is considered as a proxy for the efficient endogenous decisions case.

The conclusion arising from the analysis, is that a weak understanding of microeconomics foundation of growth, missing the role of management, has a biased effects for a comprehensive status about the underlying complexity of economic growth. Moreover, the empirical weakness of the accounting ex-post approach of economic growth focused in input quantities, does not provide a conclusive framework for policy decisions, about the tradeoff between energy and growth.

The subject is developed as follows. The initial section, begin with an overtime perspective of the main growth theories, and the empirical evidence about the explanatory macroeconomic variables of economic growth, as well as the causality relationship between energy and growth. The second section, analyzes the Microeconomic of economic growth, focusing in the production function, its link to energy and growth, and its microeconomics foundations. The Third section, provide a perspective about environment, economic growth, and the empirical significance of the Environment Kuznets Curve (EKC). Finally, the right mix of technological changes, new knowledge-intensive productive process, more efficient energy sources, and institutional improvement to ensure the property rights of environmental resources, as well as private firms with its microeconomics foundations about producer and workers decisions, will improve the aggregate efficiency level, such as to have a better interaction with the environment, and further reduction in the $\mathrm{CO}_{2}$ emissions. 


\section{Energy and economic growth: A review of the main growth theories}

The economic growth literature may be considered as a scientific effort intended to analyze its explanatory variables. As a general description, those variables are limited to just a few: income, investment ratio, population growth, political stability, market distortion and financial markets. All of them, of macroeconomic nature, whose explanatory significance depend on its specification, bias the reliability of the empirical results.

Over the period of time, 1928-1990, there are three cycles of theorizing about long run economic Growth:

- 1928-1847: Ramsey (1928), Harrod (1939), and Domar (1947)

- $\quad$ !950-1965.Neoclassical theory. Solow $(1956,1957)$, Arrow $(1961,1962)$ Kuznets $(1966)$

- $\quad 1970.1990$ New growth theory, Lucas $(1988)$, Romer $(1989,1990)$

In those years up to the 70s, there was not any indication about either the environment as a constraint, or the tradeoff between the energy sources and $\mathrm{CO}_{2}$ emissions. Todaro (1981). Therefore, the main theoretical framework which supported the empirical evidence about economic growth, was done with the environment as a common good.

The neoclassical theory of growth, has three approach based on a framework of exogenous sources models, as determinants of growth:

- Descriptive theories focused on long run USA economy growth, and the statistical significance of saving, investment, labor and capital income in aggregate output, starting with one sector model Solow (1956,1957),Kuznets (1966), and afterward a two sector model Uzawa.(1961,1963).

- $\quad$ Normative theories, focused on the saving pattern over time, within an intertemporal social welfare function. Ramsey (1928)

- The eclectic or Positive approach and the two path of economic growth: The one related to the saving - investment equilibrium (warranted Growth rate), and the other determined by the labor force growth and technical change (Natural Growth rate). Harrod (1939)

The implication of the neoclassical models, is that the initial $\mathrm{K} / \mathrm{L}$ ratio and exogenous technical change, determine the long run rate of growth. Short run economics shocks, do not have long run effect on both, consumption and the output growth trend. Solow (1957). Moreover, the key parameter from the CobbDouglas production specification, was the total factor productivity, such that short run economic policies, did not have influence on economic growth. The focus was in growth accounting, splitting the long run growth component, between inputs increases (quantity), and total factor productivity, without any further consideration about input quality, and its effect on productivity .-

These conceptual development about growth theory, used different definitions concerning the production functions, its inputs and functional characteristics. The exogenous growth models representation, was the two inputs Cobb - Douglas production function, with constant return to scale, and the substitution elasticity equal to unity. It was a simplification which left the unknown variables as residual.

Lucas (1988), and Romer (1989), doubted that economic policies did not matter for economic growth. They proposed instead, a model with technological change as endogenous, arising from the accumulation of knowledge and human capital endowment, coming from forward looking and profit 
maximizing economic agents. Furthermore, this approach, assumed that technical progress may be induced by microeconomics (Innovation), and macroeconomics (fiscal policy, population growth) variables.

\subsection{Empirical evidence about economic growth}

Concerning the issue of convergence to the steady state, the empirical evidence provided two versions: the strong and weak convergence conditions. So, it was not evident that the conclusions were reliable enough for policy purposes. This outcome is explained by a variety of factors, such as the quality of data and assumptions, the appropriate methodology for cross sectional econometrics analysis, and a weak theoretical foundation, to explain the relationship and interaction of different factors, other than ex post account measures of growth. Srinivasan (1995).

Moreover, despite Solow's model proposal (1956), what mattered for the USA economy, over the period of 1945-1985, it was not the total productivity factors, but the quality of input. In terms of value added, capital accounted for $44 \%$, labor $34 \%$ and productivity 22\%.Jorgenson (1990). Besides, the assumption of a specific sector production function linked to industrial sector, to be representative for the whole economy, did not have empirical support. Moreover, the assumption of constant return to scale, biased the real economy performance concerning return of scale, when it followed a path different to the one expected. Boskin and Lau (1992).

It turned out, that the main stream of economics models about economic growth, underestimate the role of energy, due to different explanations:

- Economic growth deals with the proper allocation of scarce resources. Energy was not considered a scarce resource previous to the oil crisis, so there was not resource allocation dilemmas.

- While other inputs may be substituted into the productive process over time, energy cannot.

- Energy was a common good, with no trade off with the environment. So, it did not have distributive implications out from the productive process.

- Environment as a common good, did not represent a constraint to the source of energy used, so there was not necessary to look for cleaner energy sources.-

- The focus of economic growth, was mainly about the production of goods and the necessary inputs to do so.

However, no matter the above argument energy availability had an impact on economic growth. While in the long run may be a constraint, in the short run, its scarcity may reduce it. Therefore, this argument lead to a new branch in growth theories, which was focused in energy and its causality effect on growth.

\subsection{Empirical evidence about energy and economic growth}

The empirical evidence about the relationship between energy, growth and pollution, does not provide conclusive results to solve the causality effect, making the setting of a consistent theoretical framework for public policy recommendation, a complex issue. Acaravci and Ozturk. (2009), suggest to classify these models in three categories:

- Those which test the Environment Kuznets Curve Hypothesis (KHC), and its "U" Inverted relationship, between growth and environment deterioration. 
- $\quad$ Those related to the nexus between output and energy, in which output and economic development are jointly determined, so that energy demand depend on economic development.

- The eclectic view: A mix of the previous approach which analyze the dynamics relationships between energy, growth and pollution.

Within the eclectic research group, over a period of time of 45 years(1960-2005), and a sample of 19 selected European countries, only five (5), (Denmark, Germany, Greece, Italy and Portugal), have a positive long run elasticity of emission and energy consumption. Acaravci and Ozturk,(2010).

There is also a positive long run elasticity relationships, between carbon emissions and real GDP, in Denmark, (1\%), and Italy (5\%).In other countries (Germany, Greece, Portugal, Iceland), it was not statistically significant. -

On a different period of time (1978-2009), the outcomes of research and the empirical evidence about energy and growth, may be categorized in four groups:

- No causal relationship or as it is called the "neutrality Hypothesis" .So, any policy about energy consumption, does not have any effect on growth.

- The one way (unidirectional) line of causality; which goes from economic growth to energy consumption. This, is also known as the "conservation hypothesis". It means that a conservation policy about energy, does not have effect on economic growth.-

- The one way (unidirectional) line of causality, which goes from energy to economic growth. This is known as the "Growth Hypothesis". In this case, restriction about energy, may be a restriction on growth. While the opposite, may support growth. However, it is difficult to assess the causality relationship between energy consumption and economic growth. Besides, due to econometrics specification, different time span and countries characteristics, there was not a conclusive outcome. Ozturk(2009). Different matrix of energy sources, regulatory framework, cultural values, institutional design concerning the rule of law, the knowledge and information endowment to influence the learning by doing process, it all adds up to decisions which have to be made, such as to have an impact on the causality between energy and growth. These decisions process, do not seem to be part of the specifications.

- Two way line of causality. It means that there is mutual dependence between energy and growth. It is called the "feedback hypothesis".

Stern \& Cleveland (2004), found that the shift in the energy matrix, from fossil fuel (Carbon) to a better quality energy input (electricity), led to a lower energy per unit of output in advanced economies. This change, is a signal about the substitution effect impact, when it comes to seek more efficient source of energy.

\section{The microeconomics of economic growth}

The state of the arts on economic growth and its determinant, seems to suggest that more attention is needed to its microeconomics foundations.

Following Stern (2010), and Knoblach and Stöchl (2019), let consider a wide range of input combinations to get a production level to become:

$$
\left(Q_{1} \ldots Q_{\mathrm{m}}\right)=f\left(A, X_{1}, \ldots, X_{\mathrm{n}}, E_{1}, \ldots, E_{\mathrm{p}}\right)
$$


"Q" represent different output levels of goods and services; "X" are different inputs such as capital and labor, "A" represent the state of technology measured by TPF. "E" represent energy variables. In this model, the relationship between energy and output can be affected by:

- $\quad$ Substitution between energy and other inputs

- Technological change

- Shift in the composition of energy matrix

- $\quad$ Shift in the output composition

However, the same production function but focused on creating value, may be written in the following way

$$
\left(Q_{1}, \ldots Q_{\mathrm{m}}\right)=M\left(b^{\mathrm{f}}\right) f\left(A, X_{1}, \ldots, X_{\mathrm{n}}, e_{1}, \ldots, e_{\mathrm{p}}\right)
$$

Where " $\mathrm{X}$ " represents all a variety of both production and organizational factors, " $\mathrm{e}$ " means the energy inputs. "A" represent the state of technology defined by total productivity factor. "M" represent management as explicit exogenous variable, with $\left(b^{f}\right)$ as an efficient parameter $(f>0)$. This new variable add new causality effects between energy and output, are linked to business decisions such as:

- The efficient mix of alternatives energy sources, to get more or less $\mathrm{CO}_{2}$ emissions like in the mining industry case, using solar energy.

- Faster implementation of different sources of technologies, making the dynamic of technological change, a matter of business decisions aimed at strategic value added goals

- Higher factors productivity within firms.

- Higher mobility of resources

- $\quad$ Firm policy about factor substitution, and its technological feasibility.

All of these options mean higher value added due to management decisions, which may have impact on the aggregate macroeconomic variables, and its causality relationships between energy and growth -

To define input relationships focused in create value, the energy input ("e), is normalized by an air pollution index, to get its net impact on value added. Different kind of energy input may have different impact on $\mathrm{CO}_{2}$ emission, so the pollution index value would be lower for cleaner energy input, and higher for fossil energy input. Therefore, the value added in the former case would be higher, than in the later.

Moreover, management allows to consider institutional variables, such as the regulatory policies, stakeholders focus, workers, consumers, community and its commitment to a clean environment, very much close to the current framework most business apply. It also set in, the role of cultural values, ethics orientation and corporate principles for a firm to be engaged with the environment protection. Furthermore, it decides the amount of capital and labor to get into the production process, which allows to consider the effect of efficiency on production levels, as well as workers motivation, to enhance their human capital to increase the quality of their flow of labor services respectively. 


\subsection{The Production function and its link to energy and growth}

Production function are usually the target of econometric analysis. Applied Macroeconomics use to regress manufactured single firm output, on inputs like capital, labor and energy to get the significance of its parameters for policy purposes. The substitution among inputs into the production function, is an issue of particular relevance for neoclassical growth theory. The easier the inputs may be substituted, it is more likely that the economy can transform the relative abundancy of one input, into further output.

From the macroeconomics stand point, the elasticity of substitution influence the reaction of firms to change in interest rate, the input reaction to increase in trade, and the share of labor in income (when $\sigma>1$ ). In terms of economic growth, the elasticity of substitution is more decisive, than technical progress. Daniels and Kakar (2017).

If Elasticity of substitution is high enough $(\sigma>1)$, growth has no limit even without technological progress. Knoblach and Stöckl (2019). Besides, the decision to invest in energy saving technology, is directly influenced by the elasticity of substitution between capital and energy. If both goods are substitutes, saving technology investment, may be transformed in capital. But if both goods are complementary, it may delay the investment on new technologies.

There are different kinds of elasticity of substitution: the Hicks elasticity of substitution (HES), the Allen elasticity of substitution (AES) and the Morishima (1967), elasticity of substitution (MES).Lagormarsino (2018).

From a structural point of view, other alternatives measures are: the usual input level elasticity of substitution $(\sigma)$, the aggregate elasticity (AES), and the effective elasticity of substitution (EES), which it is influenced by technological and no technological factors. Knoblach and Stöckl (2019).

There is also a dual dimension for substitution elasticity such as net/gross and short/long run depending on the type of econometrics model used for estimation. Those cross sectional analysis measure long run elasticity, while the time series models measure the short run elasticity. Thus capital and energy, are substitute in the long run, and complements in the short run.

These precisions are relevant, because the model regressions outcome about energy and environment relationships, are very sensitive to changes in the elasticity of substitution. Thus, although energy prices increases are higher than capital prices, the degree of substitutability between energy and capital, becomes stronger that the substitutability between capital and energy. So, higher energy prices, do not always induce the implementation of energy saving technology.

Moreover, the Substitution elasticity, provides insight about the cost of reducing energy consumption, changing the capital stock endowment to increase energy saving machinery. So, whether substitution elasticity between energy and capital is low, (both inputs as complements), it means that to reduce energy consumption, while holding output constant in the short run, it will requires higher amount of capital. In case of fulfilling emission targets, the cost in terms of output, will be higher. Lagomarsino (2018)

For an extended period of time, the growth theory was based on the assumption of elasticity of substitution equal to unity, which was the characteristics of the Cobb-Douglas production function. However, after the Arrow CES function (1961), and the empirical evidence of substitution elasticity below unity, it allowed the application of the more flexible CES function. In this function, when $\sigma<1$, it means inputs are gross complement, while $\sigma>1$ means that inputs are gross substitutes. Daniels and Kakar (2017)

There is evidence with a wide range of values for the substitution elasticity. A survey about the research done for forty years since the sixties, found that elasticity parameter was below unity. Pereira 
(2003). Later that decade, other studies found evidence of the substitution elasticity between 0,4 and 0,6 . Miller (2008).

For the aggregate USA economy (1961-2017), the substitution elasticity was between 0,3 and 0,7. But, in the same years within the manufactured sector, its value range was between 0,6 and 0,8 . This different outcomes, are an indication of how difficult is to get the proper measure of substitution elasticity, and how problematic was to keep the Cobb-Douglas production function in theoretical models, as a reliable tool for the determinants of growth. Knoblach and Stöckl (2019).

Besides, given that the elasticity of substitution, can be considered as a measure of the efficiency of the productive process, it would be unrealistic to assume that such efficiency, arise spontaneously, without any management intervention. For better or worse, management decisions, influence organizational efficiency. It follows that, there is no production efficiency, while other organizational functions works inefficiently. In other words, production efficiency is a share of the efficiency at all levels within the firm, arising from a systemic relationships, which is the subject of management performance.

Thus, the outcome arising from the literature, concerning the relationship between capital and energy, is far from being conclusive. There are different explanations for that situation, such as: the assumption about production function, different concept about elasticity of substitution, econometric models specification, and the economic context and data characteristics.

However, the empirical evidence also suggest to be cautious. CES production function no linearity, and restrictive on input (homogeneity, strong Separability, and constant elasticities), requires a procedure to test whether a (nest) CES function with more than two inputs, describes a given data. Henningsen, \& Henningsen G, (2011)

The Standard linear regression tools, do not work properly to estimate the parameter of the CES production function. There are two alternatives linear single equations estimator, for the elasticity of substitution. The one proposed by Arrow (1961), and the other by Kmenta (1967).Assuming perfect competition in both goods and input markets, and constant return of scale, Arrow proposed the first order condition of profit maximization in log form, to set the estimation equation. Kmenta(1967), suggested a more flexible approach, to expand the CES function, into a second order Taylor series, in the proximity of

$\sigma=1$. However, the outcome is very sensitive to extreme values of $\sigma$ (very low or very High). Knoblach and Stöckl (2019)

A Monte Carlo three stage simulation process, provide a test to identify the production function which does fit the data. An empirical test was done with the EU-KLEM data, which suggested that a nested CES function was appropriate to fit those data. Energy and capital within an inner nest, mixed with labor and material at an outer nest, are the one which represent UK production technology data. Lagomarsino (2018)

\subsection{The micro foundation of production functions}

The empirical evidence about the transition from stagnation to growth, has led to some inconsistency of the non-unified growth theory. So, a unified growth theory has become very important given the emergence of human capital as a relevant factor, as well as the divergence in income per capita, and a shift to a sustained growth as a social requirement.

This unification has two dimension: The integration of the whole process of economic development, and the unification of the micro foundation of the economy. This micro foundations, deals 
with those endogenous factors which changes the economy setting, leading to different choices throughout the stages of economic growth. Galor (2012)

Human capital, has been the main driver for endogenous growth theory, especially focused to provide a broader scope of growth, beyond its accounting setting, which is just an ex post measure of economic activity. Therefore, the issue became to set a framework for understanding the endogenous variables, behind the determinants of growth. Romer (1989)

The key definition of endogenous growth theory, is given by the form of $\mathrm{Y}=\mathrm{AK}$, with "A" representing technology, and " $\mathrm{K}$ " representing both human and physical stock of capital.

Lucas (1988).In this expression there is no diminishing marginal return of capital, due to either some externalities or the quality attributes of the capital stock. This one, offsets the propensity to decreasing return. This quality attribute, arises from research and development, to provide continuity to growth over time.

However, it has been difficult to get an effective measure of those externalities. Even so, this model offer an alternative explanation for technological change, different to those exogenous variables. Instead, it provides a framework to explain endogenous forces, leading to technological change. Romer (1989, 1990a), Park (1994). Moreover, it may be assumed that firms following the same pattern in terms of human capital endowment, generates spill over, innovation and value added effect, with a positive impact in the aggregate efficiency for the economy as a whole.

The microeconomics of production function, means to have a better understanding about the underlying variables, which influence organization decisions as an efficiency driven entity of resources allocation. Macroeconomic production functions, should be derived from microeconomics foundations.

A better understanding of the microeconomics foundations of a normalized CES function, should allow a more reliable explanation, about the factors explaining changes in the elasticity of substitution. Klump, Mc Adam and William (2011).

The empirical test for other format of microeconomics specification, are still in progress. Daniels and Karkas (2017).So far, there are few approaches to this microeconomic analysis of production function: The endogenous technology choice, and the mechanization setting. Knoblach and Stöckl (2019).

\subsubsection{Endogenous Technology choice.}

It assumes that production technics, are the outcomes of ideas which arise over time. It identifies a local production function, as proxy for the set of new ideas, such as:

$$
Y=F\left(b_{\mathrm{t}} K, a_{\mathrm{t}} L\right)
$$

$b_{t} \geq 0$, and $a_{t} \geq 0$ are capital and labor augmenting parameters respectively in time " $t$ ", which normalize the output "Y". Thus production function, has constant return to scale and both inputs are complementary, which means that the elasticity of substitution is below unity. Besides both inputs, may be used in fixed proportions. So, the production depend of new ideas to mix both factors, leading to a Capital -Labor ratio, and the technology frontier function of new ideas:

$$
H(a, b)=N
$$


Those more capital efficient technologies, are not suitable for the same efficiency level in labor input, and vice versa. The endogenous technological decision, can be set as an optimization problem, whose constrain are the equation (3) and (4). The Global production function becomes:

$$
Y=F(K, L, N)=\max \dot{\mathrm{F}}(b K, a L)
$$

"Y" is the highest possible output a firm is capable to produce Given " $\mathrm{K}$ " and "L", whether it is free to choose the production technique, arising from the stock of available ideas. This production function converges in the long run, to a Cobb-Douglas production function, if "a" and " $b$ " are randomly selected from a Pareto distribution. However, under certain conditions, it may also become a CES function. Knoblach and Stöckl (2019).

This approach, does not explain neither the human capital requirement to provide a stable flow of good ideas, nor how to cope with its depreciation rate, to make sure that good ideas are the rule, instead of the exception. Moreover, it does not define the cost that firms has to pay for those ideas, and how to protect them from competition forces, to keep it exclusive as a necessary condition to keep the production level which maximizes profit.

\subsubsection{Capital accumulation and mechanization}

This is the second for a production function set endogenously. The key driver in this model, is the automatization which replaces workers at an increasing rate. The long run production function, arise from different short run production function, and the firm produce intermediate goods, using either labor intensive or capital intensive technology. As mechanization goes on, capital replace labor and become the main input for production. Given the assumptions of the model, (productivity of capital relative to labor fall over the production path, and there is no constraint to mechanization) a long run CES function can arise from different Cobb-Douglas production functions, each one representing a unique levels of mechanization. Nakamura (2010)

This model, provides some guidelines about the impact on the production function of the automatization process, leading to an increase in capital as the driver input, as well as the problems different industries have to solve to keep the pace, while the automatization take place in more advanced sectors. In particular, there is heterogeneity between industries and productive sectors, about its flexibility to adopt the automatization at the same pace of those on the lead. This mean that lagged effect about the pace of mechanization, are a constraint to be considered, to identify the more appropriate optimal path.

\subsubsection{Endogenous efficiency choice}

The mainstream growth theories, do not include energy as a relevant input. So, for the sake of a more consistent explanation of economic growth forces, it is necessary a unified synthesis of Solow model, transforming a CES production function into a model of two equations, Stern (2010)

$$
Y=\left[(1-\gamma)\left(A_{1}^{\beta} L^{\beta} K^{1-\beta}\right)^{\varphi}+\gamma\left(A_{\mathrm{e}} E\right)^{\varphi}\right]^{\mathrm{i}} /^{\Phi}
$$

Equation (6) has labor (L), capital (K) and energy (E), as its inputs 


$$
\Delta K=s(Y-P e E)-\delta K
$$

Then, $\phi=(\sigma-1) / \sigma$, where $\sigma$ is the elasticity of substitution between energy and value added by other inputs (capital, Labor). The " $\gamma$ " parameter, represents the energy proportion in the production process. "A" is an efficiency parameter.

Equation (7), indicates the variables which explain change in the capital stock, which has "s" as the fixed proportion of saving out of output, and " $\delta$ " represent the constant rate of depreciation rate of capital. The price of energy in Stern's case, is a constraint to the stock of additional capital.

However, this synthesis does not consider neither the worker nor the management as maximizer economic agent, so it does not explain on the one hand, the worker allocation of time between works and other alternatives activities to maximize utility, and on the other, the efficient management decisions leading to maximizing profits .-

The CES function has some advantages and characteristics which are worth to mention:

- It includes all kinds of returns

- It may considers more than two inputs (Energy, Labor, capital)

- If "K" and "L" are perfect substitutes, an increase in "K" will require less "L", which means that marginal productivity of labor $(\mathrm{L})$ will rise. Therefore, the marginal product of an input will increase, when the quantity of the other increase.

But it also has some weakness:

- With more than two inputs CES production function, become a nest function with inner and outer zones, making its empirical estimation more complex

- In its standard version the efficiency parameter (A), cannot be independent from the other inputs.

- The parameters of the CES function, may have multicollinearity which influence the quality of estimations.

With management variables into the CES function, it allows:

- To define the link between energy and growth, not only as a matter of operational requirements, but also as a matter of business strategies efficiency, and organizational values.

- Technical changes, would count on its specific technological impact on each firm, and its financial results. Thus, management evaluates the scope of technical change relevant to firm efficiency, capital stock and organizational requirements, which lead to different aggregate pattern of adjustment to technological changes.

- The impact of technological changes, is not simultaneous across the industry, due to firm specific management decisions framework

- The institutional variables such as environment, labor, consumer and stakeholder groups as the determinant of investment and growth.

In terms of business internationalization, management allows a better understanding about the growth pattern concerning:

- Massive incorporation of technology into production and management processes, data transfer, information, and communication, supporting conditions of high mobility of goods, services and capital leading to subsequent gains in efficiency. 
- Systemic forward thinking on management leaders, to understand the expected impact on environment of their business models.-

- $\quad$ The Geostrategic goals, support the substitution away from old sources of energy, to new ones like solar, and wind power.

- Cultural aspects, influence work attitudes, values and organizational beliefs, which have a considerable impact on the performance of companies, and should not be underestimated. Adugudaa (2012).

So, the Stern (2010) proposal, may be improved with a more consistent microeconomics foundation, such that the CES production function becomes:

$$
Y=M(b)^{\mathrm{f}}\left[(1-\gamma)\left(A_{\mathrm{lk}}^{\beta} l^{\beta} k^{1-\beta}\right)^{\varphi}+\gamma\left(A_{\mathrm{e}} e\right)^{\varphi}\right]^{1} /^{\phi}
$$

From the above equation (8), The exponent of the management efficiency parameter $\left(b^{f}\right)$ is $f>0$, which means management does reduce transaction cost, to choose the proper input combinations and its service flows, as well as its organizational process. The $\mathrm{A}_{\mathrm{lk}}$ and Ae parameters, are the energy augmented efficiency factor which are linked to both microeconomic (operational requirements), as well as macroeconomic (environment policy commitment) decisions. The "e" parameter, represents energy input normalized by an air pollution index. It also influence the capital input, which fit the efficiency standard of dioxide emission.

For the sake of efficiency and resources mobility, the price of energy, labor and capital are all at its social value. It means there is free mobility of all resources, within a competitive markets for all factor of production and no negative externality effects.

$$
\Delta K=b_{\mathrm{k}} \Delta k=\Delta k=s(Y)-\delta k
$$

In equation (9) " $k$ " represent the capital stock, which depreciates at the rate " $\delta$ ", adjusted by an efficiency capital parameter $\left(b_{k}\right)$.

In this model, labor is determined by its efficiency and expected utility maximization arising from its job performance, which link the technological progress to endogenous variables like Knowledge ,innovation and Human capital, such as that " 1 " in equation (8), is the labor (L) adjusted by the efficiency labor parameter $\left(b_{1}\right)$.

$$
\Delta L=b_{1} \Delta l=\Delta l=\rho(1-\mu)
$$

Equation (10) means that workers are utility maximizer individuals, who allocate their time between labor $(\mu)$ and other alternatives activities $(1-\mu)$, such as human capital improving which lead them to get higher efficiency standard, over the time span of their working life cycle, which they are well aware of. Besides, they do provide consumption and saving rates at a positive rate. This imply on the one hand, that they substitute different works places along their working life span, and on the other, it means that Management count on that efficiency for making its investment decisions in order to get the necessary quality input combination to increase both organizational $\left(b^{f}\right)$, and operational productivity and efficiency $\left(b_{\mathrm{k}}\right.$ and $\left.b_{\mathrm{l}}\right)$ parameters. 
The utility maximization of workers is represented by the following equations, Becker (1976)

$$
\operatorname{Max} U=f(g, o)=U f\left(Z_{\mathrm{i}}\right)
$$

Where "g" are goods and "o" others goods (leisure, training, knowledge, ideas), which both require time. So, the time restriction $(24 \mathrm{~h})$, means that the individual allocate time to work, and time to consume. Thus

$$
T \mu+T_{1-\mu}=24=\dot{T}
$$

In equation (12) $T \mu$ is the time devoted to work, $T_{1-} \mu$ is the time devoted to goods consumption, such as knowledge, training, reading, durable goods and the like. Both cannot be greater than $24 \mathrm{hrs}$.

The budget constraint is given by:

$$
\Sigma p_{\mathrm{t}} g_{\mathrm{t}}+\Sigma p_{\mathrm{t}} o_{\mathrm{t}}=w T \mu=I_{\mathrm{t}}
$$

Where $I_{t}$ is the total income at any time " $t$ ". " $w$ " is the efficient wage rate, "T $\mu$ " is the hours worked, On the left side, it is the total expenditures in all goods which requires $1-\mathrm{T}_{\mathrm{u}}$ hours, whose value is given by the wage rate. Thus, there are two budget constraints.

From equation (12), comes out

$$
T \mu=24-T_{1-} \mu
$$

Replacing (14) in (13), it arises the unique budget constraint, as follows

$$
\Sigma p_{\mathrm{t}} g_{\mathrm{t}}=w\left(24-T_{1-} \mu\right)
$$

Which leads to:

$$
\Sigma p_{\mathrm{t}} g_{\mathrm{t}}=24 w-w T_{1-\mu}
$$

The budget constraint becomes:

$$
\Sigma\left(p_{\mathrm{t}} g_{\mathrm{t}}+w T_{1-\mu}\right)=w \dot{\mathrm{T}} \mu
$$

The left side represent the full direct $\left(\mathrm{p}_{\mathrm{t}}\right)$ and indirect $\left(\mathrm{T}_{1-\mu}\right)$ price of each activity, which are subject to the total income arising from $\dot{\mathrm{T}}$, the total time available for working and " $\mathrm{w}$ " the efficient wage rate for hour worked.

The equilibrium condition leads to:

$$
\left.\operatorname{MRS}(o, g)\right|_{\mathrm{u}}=w
$$

From equation (18) any individual maximize his/her utility, choosing the optimal amount of hours devoted to work, while the MRS between goods, and other goods get equals to the efficient wage rate. 
Thus, individuals enhance their human capital endowment, which has spillover effects in terms of innovation, new ideas, and creativity, that both any individual and management are well aware of, so it leads to higher wages.

As "w" rate changes, it generates substitution and income effect. The expected impact on hours worked assuming constant the productivity of time, suggest that when the income effects $>$ than the substitution effect, hours works will decrease.

The opposite which is that Income effect < than the substitution effect, means that hours worked will increase. It follows that sooner than later work will have deceasing marginal utility, which allow individual to substitutes jobs over time or at the end of his/her working life to retire.

This model may be extended to the case that individual has two jobs. The utility function considers two vectors, one of goods, and the other of alternative jobs:

$$
\operatorname{Max} U=f(X, W)
$$

Where "W" is the time spent at work, while " $\mathrm{X}$ " is consumption. It concludes that wages, do not necessarily match the marginal private value of working. Chiswick(1967). This conclusion, suggest that individuals may not have exclusive stable commitment to each of their jobs, as much as they have the expectation of finding another one doing on the job search. Somehow, from the intertemporal perspective, workers are constantly searching for alternatives jobs, which is an incentive for management to keep competitive wages.

The allocation of time model, has been improved throughout a continuous research, either to reassure the Becker original proposal, or to make corrections about its scope. Train and McFadden (1978) worked in a two stage format, the initial one to set the optimal allocation of goods and time, given a particular set of alternatives to get the indirect utility function, to choose in the next stage, the combination with the higher utility. Astroza, 2012).

Moreover, Jara-Diaz (2003) based on Train and McFadden (1978), assumed a Cobb-Douglas type utility function, to propose that the time allocation for working, depend on the wage rate and the transportation cost.

The empirical evidence about the allocation of time model, shows that Chileans ( 42 years old) spent on average 51,3h weekly in their jobs,96,8h at home, and 4,4h in leisure and $15.6 \mathrm{~h}$ in other goods .As expected, time at work and at home, are negatively correlated. Olguin (2008). It follows that age, is a relevant variable for the optimum allocation of time between work and home. This results are not different taking as a sample, the average American. They spend $98.8 \mathrm{~h}$ weekly at home, and 41, $2 \mathrm{~h}$ at work. However, the fewer hours they allocate to work, is consistent with their higher income. They work less hours than their Chilean counterparts. There is also in this case, a negative correlation between hours at home and hours at works. Astroza (2012)

Therefore, management set a production function which maximize profits, with technology change driven by a set of joint variables like efficiency, productivity and quality inputs requirements, to get value added on the whole organizational process, which lead to investment on machinery, equipment and human capital. On the side of workers, they get a wage rate, which allow them to choose the optimal combination between works and other activities (human capital improvement), to increase their expected income flow over their working life cycle. At the same time, they allocate income between consumption and saving.- 
Moreover from the management stand point, both current and expected profit maximization goal lead to higher capital mobility (internationalization, globalization), to cope with short run diminishing marginal return. On the other hand, workers and their current and expected utility maximization goals, leads to higher labor mobility between geographical places (migration), firms, jobs and income alternatives (entrepreneurs ).

Thus, from the intertemporal perspective, both firms and workers take decisions leading to more efficiency and increasing productivity. Whether management is unable to adapt to this dynamics, it would lead to inefficiency. The marginal decreasing return of the organization management will arise, before it starts the marginal decreasing return of other inputs. Wulf (2016)

This endogenous efficiency model proposal, within the utility-profit maximization framework, give some guidelines about the expected impact that labor mobility, human capital investment, optimal time allocation between alternative activities, and management decisions, have in both the organizational efficiency for minimizing the cost on environment, and the significance of key input, for the economic growth.

Growth experiences, such as that of South Korea and East Asian countries , mostly attributed to a total factor productivity increases, may be explained by microeconomic optimizing decision at firms and workers levels. Higher expected wages coupled with utility maximization, was an incentive for labor migration from rural to urban places, providing a positive supply side shock of better human capital endowment, setting management of South Korean firms, to get down labor cost and so doing, increasing the efficiency and technical progress embodied in new equipment investment, which grew at $4 \%-5 \%$ rate (y/y).

In Japan and new industrialized countries (Hong Kong, South Korea, Singapore and Taiwan), 80\% of its growth was explained, by capital accumulation and relatively little arising from productivity growth. Kim and Lau (1992).

The discussion about the sources of growth in East Asian countries (EAC), became a policy issue after the expected impact of its crisis in 1997-1998. The source of its past economic growth, had implication for keeping its future stability at that time, but also for those countries which had in the East Asian experience, a benchmark to follow.

Factor accumulation or total factor productivity increases, are of different nature and so are its implications. Therefore, the research has followed two lines of analysis, the "accumulation view", which was focused on the factor accumulation, and the "assimilation view", which was focused in total factor productivity, as the source of growth in EAC.

The assimilation approach, was the focus of the main stream growth theory, following the assumption of Cobb-Douglas accounting perspective, of economic growth. For international organizations (World Bank), the hypothesis was that TFP growth, was explained by the implementation of economic policy reform, openness to trade, and technological innovation. Another perspective to explain the EAC case, came out from taking into account, the best international management practices in the export orientated manufactured sector, as a condition to get successfully into world markets. Park (1994).

This lines of research, were challenged by empirical data relevant at the time it all started, (1950), which supported that the East Asian economic growth, was driven by input increases. Thus, over the period 1950-1965, the growth rate of South Korea was 6, 2\%, with input labor contributing $2.9 \%$, (almost $50 \%$ of the overall rate of growth), Capital $2.2 \%$ and TPF,1-1\%. 
Over a sample of 22 countries for the same period of time, the average growth rate was $5.5 \%$ with input labor contributing $1.9 \%$ (30\% of total output growth rate), Capital 3.1\%, and TPF, $0.5 \%$. Maddison (1970).

So, at the beginning in the earlier stages of the economic growth expansion in South Korea and other LDC countries, labor input quality was a key driver. A similar outcome, is what the empirical evidence show over the period 1964-1990, for African countries (Kenia, Tanzania. Zambia and Zimbabwe), with input labor contributing to economic growth almost a third (1/3), while TPF, was negative or zero (Zimbabwe).

For Latin American economies, over the 90s decade, the average labor input contribution to economic growth was 35\%, capital input 32\% and TPF 33\%. Hoffman (2000), Masoud(2013).

The accumulation view, using the neo classical accounting approach, concluded that high economic growth rate in EAC, (1975-1990), was the result of input accumulation. In some countries, like Philippines labor input grow, accounted by 40\%, and in the EAC accounted by 30\%.ADB (2010), OECD(2013). The TPF had a small incidence to explain EAC growth. Kim and Lau (1992), Young (1995), Krugman (1994) and Quah (2008).

Thus this outcomes, suggest that at least, some of explanation factors for economic growth in the EAC, were different to those expected by the conventional wisdom, making a case for labor input accumulation in the early stages of growth, while shifting from low capital endowment, to capital accumulation. These differences, make clear the bias arising between either focusing at the quality of inputs, or at the efficient utilization of inputs.

\section{Environment and economic growth: a major concern}

Climate change has increased the attention on environment protection, and better economic policy design about it. Higher energy demand on fossil fuels (oil), leads to greenhouse gas emissions, with negative externalities for global growth and its sustainability. Environment protection, has become not only an issue about the risks involved, but also about its systemic consequences. Stricter rules has been issued in European Union countries (e.g. France, UK), to measure carbon footprint, water footprint, and greenhouse gas emissions standards. The concept of sustainable development, has become an objective of economic policies. Marhold and Meimeth (2009).

Thus, ecological economist proposal is that energy, cannot be left out from the growth equation, because traditional energy sources, have a negative trade off with the environment, leading to a social cost, to be considered in total production cost. The production function, leaves aside the technological process and factors substitution, making energy the driven force of economic growth.

As part of its $70^{\text {th }}$ session, the UN set in 17 objectives, to be part of a sustainable development program with the active participation of UNESCO, which meant a call for Clean energy (7), Industry innovation and infrastructure (9), reduce inequality(10),Sustainable cities and communities(11), responsible consumption and production(12), climate action(17)and partnership for the goals(17). UNESCO (2015).

In particular, the share of clean energy in total energy consumption for 2017 , reached $17.3 \%$ up from $16.3 \%$ in 2010.Concerning the energy efficiency over the period 2010-2017, it improved by 2.2\%.Preliminary estimates for 2018 and 2019, for the energy efficiency(energy intensity), parameter are gains of $1.3 \%$ and $2.0 \%$ respectively. UN (2020) 
Therefore, environment concern is well into the global climate change policy, for sustainable growth, as part of an institutional framework based on partnership with enterprises, to get the UN 2030 agenda.

The empirical evidence concerning climate change and economic growth suggest that:

a. - $\mathrm{CO}_{2}$ emissions are the key explanatory variable. After three year of a stable path, over the period of 2017-2018, the fossil emissions has increased again. However, a positive signal comes from a sample of 19 countries (USA and mainly European countries), which in the last decade, have reduced $\mathrm{CO}_{2}$ emissions, while keeping its positive GDP performance.

b. - Although the increase in $\mathrm{CO}_{2}$ emissions in 2018-2019 has different sources, it is also a consequence of the less developed countries, and its traditional energy sources. Jackson (2018).

c. - Over time, climate change has an impact on economic growth across countries. But, considering the year variability of monthly temperatures and precipitation, there is little effect on economic growth, even keeping temperatures stabilized at around $1.5^{\circ} \mathrm{Cs}$ and $2^{\circ} \mathrm{Cs}$. From the methodological stand point, this represent a different approach to the issue of measuring climate change impact on growth, shifting from the usual quarterly/annual measures of growth changes, to a pattern of climate change which take place in a shorter period of time (weeks/months).However, at the level of $2^{\circ} \mathrm{Cs}$ warming temperatures, a lower GDP is expected for those countries in the tropics and southern hemisphere. Pretis (2018).

d. While in earlier research, an increase in temperatures above $1{ }^{\circ} \mathrm{C}$ in low income countries, decreased output by $-1.58-2.01 \%$, most of that decrease was in agricultural product(-2,37\%), whose share is close to $50 \%$ of its GDP . Dell, Olken \& Jones (2008).

e. A sample of 20 East Asian countries, to study the relationships between income inequality and $\mathrm{CO}_{2}$ emissions, suggest that although growth impact in low income countries is high on environment degradation, it is small on inequality. Ota (2017). However, recent evidence, suggest that such GDP decrease in low income countries, may indeed lead to higher income inequality. Pretis (2018)

So, in low income countries; there is an indirect inequality effect arising from the impact in the productions conditions within agricultural activities due to higher temperatures. Thus, given its lower speed of adaptation, as well as the greater impact of climate change, the best strategy for these economies, is to deal with the effect of global warming from a three dimensions approach: a.- Intergenerational (Current Generation v/s Future Generation) b.- Inter territorial (Global Regions v/s Local Regions), and Inter sectors areas (Economy, v/s Social Affairs and Ecology). Globalization and trade in particular, has an efficiency profile, regarding the use of cleaner energy, and the subsequent substitution to less contaminant sources of energy. Gormus (2020)

Therefore, given the increasing social cost for economic growth, of using natural resources, Multinational Companies have to reshape their business strategy to get along with its stakeholders who are not indifferent to the environment protection issue, applying the Corporate Social Responsibility (CSR) management guidelines, such as to reduce the gap between private and social cost. Wulf (2017)

Within the mining industry case, the direct and indirect costs of restoring areas once its production operation is over, usually exceed between 1.5 and 10 times its preliminary estimates, which discourages effective actions dealing with post production environmental protection actions. Even though, global mining activity uses less than $1 \%$ of the planet's surface, it consumes a similar percentage (1\%) of available water, and contributes only $3 \%$ of greenhouse gas emissions, a smarter strategy beyond its own set of 
production efficiency would be to work key issues with the community, before starting any operational activities. When it comes to deal with environment, corporative image and public reputation, are a proxy for internal cultural organizational values and principles. Therefore, to get the attention of new investors, the alternatives energy sources in mining activities, like those renewable ones such as wind, solar, and geothermal sources, are a top priority in the new mining projects. Likewise, the same apply to use the limited availability of water, which requires significant investments in desalination plants, to make sure a sustainable water supply for human consumption.

Thus, to reduce social costs of business action, it all lead to a relationship with the community and better Corporative practices for management, as a proxy of social efficiency. The rationality of this approach, is that lower social cost of firm actions, has a positive impact on financial cost for investment projects, and a relevant impact on efficiency at both firms and in the aggregate level of the economy.

Concerning the CSR issue, the management of multinational enterprises, may follow an ethnographic approach, which allow to work in a macro (community) and micro level (individual), to shape its corporative governance culture as a necessary condition, to improve the organization performance.

The Corporative Governance, affects the interaction of the organization members, the decision making process, leadership style, responsibility and transparency, impacting the efficiency and effectiveness of the management. Evans (2010).The rationality behind such a Corporative behavior, is to get a better control of any risk, instead of moving forward with it. Kemp and Owen (2013).

A new leadership profile for management, is necessary to fulfill the institutional rules regarding environment protection, and increasing bottom up CSR initiatives. Communities, have better and easier access to information about business impact on environment, and they do understand the implications of legislation concerning new rules for environment protection, alternative energy sources or, stakeholders rights. Belair (2010).

To cope with the current and expected change, an organizational development strategy is necessary to be in place, applying a new way of thinking, necessary to get a substantial improvement in knowledge, interpersonal relationship, productivity, efficiency, and quality flows, to increase organization and community benefits. Esteves and Barclay (2011). The organizational culture, also play a relevant role in any attempt for implementing organizational strategies, aimed at improving the CSR commitment. It is also a key input to make sure the whole redefinition purpose becomes successful. De Oliveira (2015).

\section{The Kuznets environment curve(EKC)}

The Kuznets Environment Curve (EKC), is the relationship between growth, environment, and its causality over time. As an empirical issue, its theoretical support is still in progress, and there was doubts about the strength of its implications. Stern and Cleveland (2014) 


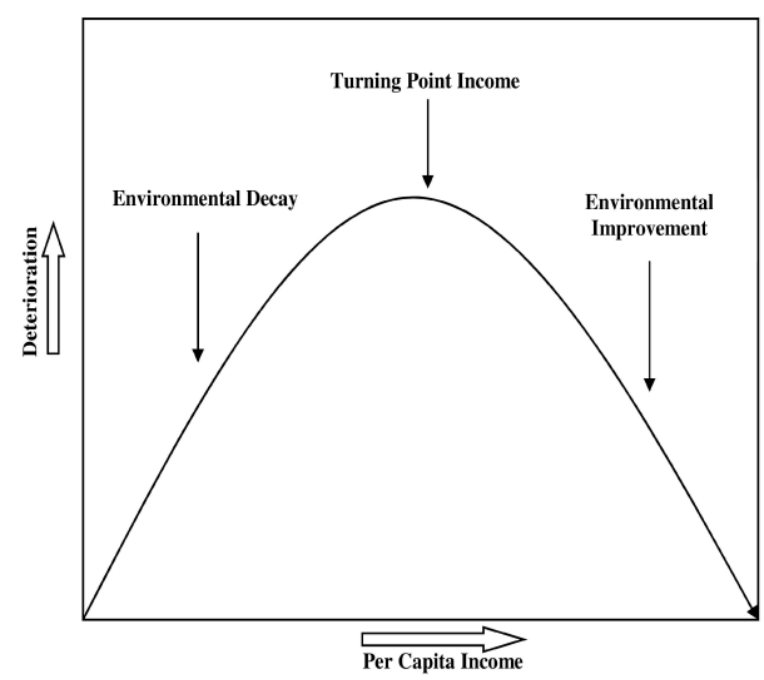

Figure 1. The Kuznets Environment Curve Source: Yandle, Vijayaraghavan, Bhattarai(2002)

The Kuznets curve propose that in the early stages of economic growth, the environment deteriorates up to a level of per capita income inflexion point, to reverse such a deterioration, making the curve an inverted "U" shape.(Figure $\mathrm{N}^{\circ}$ ). This is so, because as income grows, consumers demand higher quality goods, no matter whether it is private or public one, making income elasticity of "environment care", greater than one. So, consumer attach higher value, to protect the environment.-

But the Hechscker -Ohlin model (1977), proposed that economies specialize in the production of goods that use intensively the more abundant input. So, as economic growth gets to more advances stages, production shift from primary goods, to those more human capital intensive, decreasing the share of environment in the final output, leading to the perception of environment improvement due to other factors. A sample of the 10 most innovative economies over the period 1990-2015, to test within the setting of the ECK, the relationship between ecological foot print, economic growth, sustainable energy consumption and innovation, turned out to be relevant only in Israel, although innovation reduces $\mathrm{CO}_{2}$ in the whole sample and sustainable energy consumption, reduces $\mathrm{CO}_{2}$ emissions only in Denmark, Germany, Netherlands and USA. Gormus (2020)

This outcome, suggest that innovation as a positively externality of human capital, make natural resources less relevant in production process.

\subsection{Empirical evidence about the EKC}

The empirical evidence about the relationships between economic growth, contamination, and the EKC in particular, has been focused in three categories:

- To test the EKC, and the correlation between pollution and economic growth.

- To test the correlation between energy consumption and output

- To test a multivariable dynamic setting between energy, consumption, economic growth and contamination, which lead to the EKC hypothesis.

The EKC curve was tested, over the period 1990-2011 with a sample of 14 countries, including China and India. Apergis \& Ozturk (2014) 
The main outcomes of this research were:

- It gives empirical support to the EKC, for countries considered into the sample study.

- It means that environment degradation, increases in the early stage of economic growth, up to a maximum, then at the inflexion point it starts to decline.

- The causality direction, goes from income to emissions.

- The Institutional framework, has an important role either to support or not, the dynamic of moving from one stage about sources of contamination (fossil fuel energy), to another one (cleaner energy mix).

- The relationships between $\mathrm{CO}_{2}$ - Growth nexus, arise from a wider review of empirical studies which support the EKC relevance. Moreover, the usual "U" inverted shape, seems to fit properly the case of some developing and transitional economies. Purcel(2020) There are different lines of research, concerning specific methodologies issues.

- Cross sectional research, which gives long run support to the EKC for France and Turkey (1960-2005), Acaravci, Ozturk (2010), although in the Turkey case, was so later on, for a different period (1970-2010).Shanbaz, Ozturk, Afza \& Ali (2013)

- Panel studies, applied to 12 Middle Eastern; and 12 North African countries, give empirical support for the EKC, with the exception of United Arab Emirates, Tunisia and Morocco.

- Using a Pooled mean Group to test 12 east African Countries over the period 1990-2013, the relationship between $\mathrm{CO}_{2}$ emissions (proxy for environment degradation), and income per capita was as expected .Demissew \& Balázs (2020)

Based on a panel studies, an extension was done in the EKC research over the period 1980-2010, to include international trade for $25 \mathrm{OCDE}$ countries. The main results, gives empirical support for the Environment Kuznets curve, as well as it also supports the relevance of international trade and renewable energy sources, to reduce emission. Jebli,Youseff \& Ozturk(2015)

Empirical evidence does support EKC, to become a useful policy guideline, especially while economic growth is on the early stage. However, the relationship between energy, environment and growth which matter for current policy recommendation, is the one arising from advanced economies growth experience. This suggest that, given an institutional framework, firm management, has an important role for implementing alternative sources of energy, as well as innovation within the production process, to get a higher social efficiency in the production process, with lower levels of $\mathrm{CO}_{2}$ emissions.

\section{Concluding Comments}

The challenges of increasing energy demand, environmental deterioration and policy implementation to cope with it, cannot be solved in short run. Higher temperatures, have a negative effect on growth. So, there is critical tradeoff between environment and growth. Therefore, economic growth cannot be conceived as straight line input quantity process, leaving aside its complexity. This suggest a holistic (macro and micro) view of the economy.

The right mix of technological changes, new knowledge-intensive productive process, more efficient energy sources, and institutional improvement to ensure the property rights of environmental resources, as well as the participation of non-governmental organizations, and the community, will improve 
the aggregate efficiency level, such as to have a better interaction with the environment, further reduction in the greenhouse emissions and a properly designed policy framework.

Private firms with CSR polices, and its management model decisions based upon microeconomics foundations, with both producers and workers acting like profit making economic agent, may be able to provide the endogenous efficiency decisions, such as to increase the innovation flows to get cleaner energy sources, reducing $\mathrm{CO}_{2}$ emissions, and a sustainable path for growth and development .-

To isolate economic growth from its microeconomics foundation, leads to inconclusive results, about the real direction of causality between energy and growth. The accounting approach, measures only the ex post effect of using inputs efficiently. So, the empirical evidence about the Cobb- Douglas substitution elasticity (mostly $\sigma<1$ ), is not only an indication about the difficulties involved to fulfill assumptions researchers do, but also a signal about the biased on economic growth determinants, while assuming a Cobb-Douglas production function . Knoblach \& Stöckl(2019) .

Therefore, the empirical ground for better policy recommendations about the relationship between environment and growth, beyond innovation, is still in progress for solving that tradeoff effectively and efficiently.

\section{References}

[1] Acaravci, A, \& Ozturk, I.(2010).On the relationship between energy consumption , $\mathrm{CO}_{2}$ emissions and economic growth in Europe. Energy 35.5412-5420.www.elsevier.com

[2] Adugudaa, A. (2012).Cultural diagnosis and Bypassing. The effects of successful Internazionalization. Review of business and Finance Studies 3(1).IBFR. Hawai. USA

[3] Apergis,N. \& Ozturk,I. (2014).Testing Environmental Kuznets hypothesis curve in Asian countries. Ecological indicators 52. 16-22

[4] Arrow, J., Chenery, B., Minhas, S., \& Solow, R.(1961). Capital - labor substitution and economic efficiency. Review of Economics and Statistics , 43 (3):225-250

[5] Astroza, S. (2012). Análisis comparativo de modelos de uso del tiempo. Departamento de Ingeniería Civil. 1-90. Universidad de Chile .Santiago. Chile.

[6] Baqer, S. (2012).True Green consumer: An investigation of consumer genuine willingness to share environmental responsibility. Global Journal of Business Research 6 (3). IBFR. Hawai .USA

[7] Bhattacharya, M. Reddy Paramati, S. Ozturk, I, \& Bhattacharya, S. (2015).The effect of renewable energy consumption on economic growth. Evidence from 38 top countries Applied energy 2016.733741.www.elsevier.com

[8] Becker, G. (1976). An economic approach to human behavior. University of Chicago Press. Chicago. USA.

[9] Belair, J. P. (2010). Algunas referencias para posicionar la responsabilidad social en el escenario planetario actual. Ciclo de conferencias responsabilidad social: Un imperativo ético de una sociedad global, 13-30. Cátedra Raúl Bitran. Universidad de La Serena. Chile

[10] Ben Jebli, M. Ben Youseff,Y \& Ozturk,I.(2015).Testing Environment Kuznets Curve Hypothesis: The role of renewable and nonrenewable energy consumption and trade in OECD countries. Ecology indicators 60.824-831.www.elsevier.com

[11] Bergolth, D. (2011).A note on CES function. 1-6. Norwegian Business School

[12] Boskin, M. \& Lau. J, (1992a). Capital, technology, and economic growth. In Technology and wealth of nations, ed. N. Rosenberg, R. Landau, and D. Mowery, 17-55.Stanford, Ca: Stanford University Press. 
[13] Boskin, M \& Lau, J (1992b). Post-war economic growth in the Group-of-Five countries: A new analysis. Department of Economics, Stanford University.

[14] Chiswick, B. (1967). The economic value of time and the wage rate: Comment. Western Economic Journal, 294-295.

[15] Daniel, G, \& Kakar, V (2017).Economic Growth and the CES production function with human capital. Economics bulletin. Volume 37, Issue 2: 930-951

[16] Dell, M. Jones, B, \& Olken, B. (2008). Climate change and economic growth: Evidence form the last half a century. NBER. WP 14132.USA

[17] De Oliveira, U (2015).Ethnographic supporting Corporative Social responsibility policies and practices. Work-Based approach to social sustainable development. Doctoral Thesis. Walden University.

[18] Demissew, S \& Kotosz, B. (2020) Testing the environmental Kuznets curve hypothesis: an empirical study for East African countries, International Journal of Environmental Studies, 77:4, 636-654, doi: 10.1080/00207233.2019.1695445

[19] Dissou, Y, Karnizova , L, \& Sun, Q (2012).Industry levels econometrics estimates of energy labor substitution with a nested CES production function. Working paper 1214E.University of Ottawa. Canada.

[20] Domar, E. (1947). Expansion and employment. American Economic Review 37: 34-55.

[21] Esteves, M., \& Barclay, M. (2011). New approaches to evaluating the performance of corporate-community partnerships: A case study from the minerals sector. Journal of Business Ethics, 103:189-202

[22] Evans, A. (1972). On the theory of the valuation and allocation of time. Scottish Journal of Political Economy 19: $1-17$.

[23] Evans, G. (2010). Corporate governance culture: An interview-based ethnography of two boards of directors using grounded theory. Poznan University of Economics Review, 10(2): 15-32.

[24] Everingham, J. (2012). Towards social sustainability of mining. Greener Management International, 57: 91103.

[25] Fernandez - Ortiz, R. Clavel, M, \& Gonzalez, L. (2012).A quantitative measure of the Gradualist approach to Internazionalization . Global Journal of Business Research. IBFR. Hawai .USA

[26] Fong, C, \& Ocampo, L. (2010). Intangible Resources as a determinant of accelerated Internazionalization. Global Journal of Business Research 4 (4).IBFR .Hawai. USA

[27] Florax, R, de Groots, H, \& Heijungs, R. (2002).The empirical economic growth literature. Tinbergen Institute.1-33.Holland.

[28] Galor, O. (2012).Unified Growth Theory and Comparative Economic development. Luxemburg.

[29] Gormus, S., Aydin, M. (2020).Revisiting the environmental Kuznets curve hypothesis using innovation: new evidence from the top 10 innovative economies. Environ Sci Pollut Res 27: 27904-27913. https://doi.org/10.1007/s11356-020-09110-7

[30] Harrod, F. (1939). An essay in dynamic theory. Economic Journal 49: 14-33.

[31] Henningsen, A, \& Henningsen, G (2012).On estimation of the CES function-Revisited. Economic Letters 115(1): 67-69. doi: 10.1016/j.econlet.2011.12.007

[32] Hiroaki, S (2017).A note on the Solow Growth Model with a CES production function and declining population. MPRA N ${ }^{\circ} 80062.1-10$. http://hdl.handle.net/10419/191054

[33] Hoffman, A. (2000). Economic growth and performance in Latin America. Series Reform Economics: 1-39.

[34] Jackson, R.B. (2018).Global energy Growth is outpacing decarbonization. Environmental research letter.13, 120401: 1-8. https://doi.org/10.1088/1748-9326/aaf303

[35] Jara-Diaz, S. (2003). On the goods-activities technical relations in the time allocation theory Transportation 30: $245-260$.

[36] Jorgenson, D. (1990). Productivity and economic growth. In Fifty years of economic measurement: The jubilee of the Conference on Research in Income and Wealth, ed. E. R. 
[37] Berndt \& J. E. Triplett, chap. 3. Chicago: University of Chicago Press

[38] Kmenta, J. (1967). On Estimation of the CES Production Function. International Economic Review, 8(2):180-189

[39] Kemp, D., \& Owen, J. R. (2013). Community relations and mining: core to business but not "core business". Resources Policy, 38: 523-531. doi:10.1016/j.resourpol.2013.08.003

[40] Kim, J., \& Lau, J. (1992a). Human capital and aggregate productivity: Some empirical evidence from the Group of Five countries. Department of Economics, Stanford University.

[41] Kim, J. \& Lau, J (1992b). The importance of embodied technical progress: Some empirical evidence from the Group of Five countries. Department of Economics, Stanford University.

[42] Kim, J. \& Lau, J (1992c). The sources of economic growth of the newly industrialized countries on the Pacific Rim. Department of Economics, Stanford University. Processed.

[43] Kuznets, S. (1966). Modern economic growth: Rate, structure and spread. Yale University Press. New Haven. Conn.

[44] Klump, R. McAdam, P \& Willman, A.(2011) The normalized production function. Theory and empirics. Working Papers Series 1294, 1-52.European Central Bank.

[45] Knoblach, M, \& Stöckl, F (2019).What determines the elasticity of substitution between Capital and labor. A literature review. CEPIE Working Paper $\mathrm{N}^{\circ} 1 / 19 ; 1-36$.Technische Universität Dresden. Faculty of business and economics. http://hdl.handle.net/10419/191054

[46] Krugman, P. (1994). Fluctuations, Instability, and Agglomeration. NBER Working Papers, (4616), National Bureau of Economic Research, Inc

[47] Lagormarsino, E (2018).A study and approximation of the CES Production Function. Doctoral Thesis. Heriot-Watt University.

[48] Lucas, R. (1988). On the mechanics of economic development. Journal of Monetary Economics, 22 (1): 342.

[49] Maddison, A. (1970). Economic progresses and policy in developing countries. London: Allen and Unwin.

[50] Masoud N. (2013).Neoclassical economic growth theory: An empirical approach. Far East Journal of Psychological and Business. Volume (11) 3: 1-25.www.researchgate.net

[51] Meza,J, Barron,K, \& Urciaga,J. (2012). Recursos naturales y crecimiento económico. Analizando el capital humano en México. Revista Internacional Administración y Finanzas.5 (1).México.

[52] Marhold, H \& Meimeth, M (Eds). (2009).Sustainable development in Europe. A comparative discourse analysis. Germany. Ed Nomos

[53] Mendieta, J. (2005).Teoría del consumidor. Teoría del productor, Teoría de Juegos y competencia imperfecta: 1-177.Universidad de Los Andes .Bogotá. Colombia

[54] Miller, E (2008).An Assessment of CES and Cobb-Douglas production function. Working Papers.200805.Congressional Budget Office.

[55] Morishima, M. (1967). A few suggestions on the theory of elasticity. Economic Review, 16: 144-150.

[56] Nakamura, H. \& Nakamura, M. (2008). Constant-Elasticity-of-Substitution Production Function. Macroeconomic Dynamics, 12(5):694-701.

[57] Nakamura, H. (2010). Factor Substitution, Mechanization, and Economic Growth.The Japanese Economic Review, 61(2):266-281.

[58] OECD (2013). Economic development and performance. Chapter I: 1-49.Innovation in South East Asia.

[59] Olguin, J. (2008). Modelos de uso de tiempo a actividades para el gran Santiago. Tesis de

[60] Magister, Departamento de Ingeniería Civil, Universidad de Chile.

[61] Ozturk, I. (2009).A literature survey on Energy-growth nexus. Energy policy 38:340-349. www.elsevier.com

[62] Ota, T. (2017).Economic growth, income inequality and environment: assessing the applicability of the Kuznets hypotheses to Asia. Palgrave Commun 3, 17069 https://doi.org/10.1057/palcomms.2017.69 
[63] Pretis F, Schwarz M, Tang K, Haustein K, \& Allen M. (2018). Uncertain impacts on economic growth when stabilizing global temperatures at $1.5^{\circ} \mathrm{C}$ or $2^{\circ} \mathrm{C}$ warming. Phil. Trans. R. Soc. 1-19. A 376: 20160460. http://dx.doi.org/10.1098/rsta.2016.0460

[64] Purcell, A. (2020).New insights into the environmental Kuznets curve hypothesis in developing and transition economies: a literature survey . Environ Econ Policy Stud. https://doi.org/10.1007/s10018-020-00272-9

[65] Quah, D.(2008).Post's 1990 East Asian economic growth:1-31. London School of Economics. https://www.researchgate.net/publication/228973453

[66] Park, H (1994).Endogenous Growth Theory. Intellectual appeal and empirical shortcomings. Journal of economic perspectives. Volume 8, (1): 55-72

[67] Park, D, Park, J (2010).Drivers of developing’s Asian drivers. Past and future. Working paper series N²35:135.Asian Development Bank. www.adb.org/economics

[68] Pereira, C. 2003. "Empirical Essays on the Elasticity of Substitution, Technical Change, and Economic Growth." Ph.D. dissertation, North Carolina State University.

[69] Ramsey, F. (1928). A mathematical theory of saving. Economic Journal 38: 543-59.

[70] Rodrik, D.(2013) Past, Present and Future of economic growth. Working paper 1:1-58.Global Citizen Foundation.

[71] Romer, P. (1986). Increasing returns and long-run growth. Journal of Political Economy 94 (5): 1002-37.

[72] Romer, P. (1989).Human capital and growth. Theory and evidence. Working paper 3173: 1-51 NBER. Cambridge. Ma.

[73] Romer,P, (1990). Endogenous technological change. Journal of Political Economy 98, (5) S71-S102.

[74] Shahbaz, M .Ozturk, I. Afza, T, \& Ali, A.(2013).Revisiting the environmental Kuznets Curve in a global economy. Renewable and Sustainable Energy Reviews 25:494-502. www.elsevier.com

[75] Sarel, M. (1996). Growth in East Asia. What we can and what we cannot infer. Economics Issue 1: 1.28.IMF. Washington.

[76] Solow, R. (1956). A contribution to the theory of economic growth. Quarterly Journal of Economics 70: 6594.

[77] Solow, R. (1957). Technical change and the aggregate production function. Review of Economics and Statistics 39: 3 12-20.

[78] Stern, D. \& Cleveland, C. (2004).Energy and economic growth. Working paper in economics. 0410:143.Rensselaer Polytechnic Institute. New York. USA

[79] Stern, D. (2010).The role of energy in economic growth. Centre for climate economics and policy. (CCEP). Working paper 3 (10):1-52.Australan National University. Australia

[80] Stern, D.(2014). The rise and fall of the environmental Kuznets curve. World development 32 (8) .Elsevier Ltd. Great Britain. UK

[81] Srinivasan, T. (1995).Long run growth theories and empirics: Anything new? . T. Ito \& A Krueger (Ed). Growth theories in light of the East Asian experience: 37-70 University of Chicago Press. USA

[82] Train, K. \& McFadden, D. (1978). The goods/leisure tradeoff and disaggregate work trip mode Choice models. Transportation Research 12: 349-353.

[83] Todaro, M.(1981).Economic development in the third world. Second edition. Longman Inc. New York. USA

[84] United Nations (2020).The sustainable development goals report:1-68.New York

[85] UNESCO (2015).SDG https://en.unesco.org/sustainabledevelopmentgoals

[86] Uzawa, H. (1961). On a two-sector model of economic growth. Part I. Review of Economics Studies.29: 4047

[87] Uzawa, H. (1963). On a two-sector model of economic growth. Part 11. Review of Economics Studies 30: 105-118 
[88] Wang, X, \& Fu, Y (2013).Some characterizations of the Cobb-Douglas and the CES function in microeconomics. Volume 2013: 1-7, http://doi: org/10.1155/2013/761832

[89] World Bank (1991). World development report 1991. World Bank Washington, D.C.

[90] Wulf, E (2016) La empresa moderna .Una perspectiva de Negociación. Editorial Universidad de La Serena. Chile. www.editorial.userena.cl

[91] Wulf , E (2017).(Ed).Responsabilidad social Empresarial. Un Desafío Corporativo. Editorial Universidad de La Serena .www.editorial.userena.cl

[92] Yandle, B. Vijayaragavhan, M \& Bhattarai, M. (2002). The Environment Kuznets Curve. PERC Research Study 02-1

[93] Young, A. (1995). The tyranny of numbers: confronting the statistical realities of the East Asian growth experience. Quarterly Journal of Economics, 110 (3): 641-680. 